\title{
О. Олійник
}

\section{МУЗИЧНО-ІНСТРУМЕНТАЛЬНА КУЛЬТУРА ТРИПІЛЬСЬКОЇ ЦИВІЛІЗАЦІЇ (ДО ПИТАННЯ РЕКОНСТРУКЦІЇ)}

\begin{abstract}
Стаття присвячена питанням реконструкції ударних $і$ духових інструментів раннього та середнього етапів існування Трипільської цивілізації (4600-3700 рр. до н. е.). На основі порівняльного інструментознавчого аналізу у сакральних комплексах трипільської кераміки виявлено різні типи барабанів, що мають аналоги серед однотипних керамічних інструментів народів світу. Духові інструменти трипільців реконструйовані на основі чисельних однотипних інструментів різних археологічних культур (палеоліту - доби бронзи) та народними технологіями їх виготовлення.
\end{abstract}

Ключові слова: трипільські музичні інструменти, музична археологія, барабани, духові інструменти.

Трипільська цивілізація України є одним з найбільш яскравих і самобутніх явищ в історії давніх землеробських суспільств Європи. Перші ії пам'ятки було виявлено київським археологом Вікентієм Хвойкою наприкінці XIX ст. поблизу с. Трипілля на Київщині. Археологічні дослідження показали, що ця цивілізація проіснувала на теренах сучасних держав - України, Молдови та Румунії близько 2600-2700 років (від другої половини VI - до початку III тис. до н. е.) [3, с. 47]. У Молдові та Румунії іï називають культурою Кукутень.

Трипільське землеробське суспільство мало всі атрибути цивілізації, що визнано найавторитетнішим американським Міжнародним фондом пошуку давніх цивілізацій (Found for Research of Ancient Civilizations) [12, с. 3-4]. Воно володіло розвиненими технологіями ведення господарства - обробляли землю плугом, винайшли гончарне коло, ткацький верстат, плавили метал та будували поселення-гіганти. Трипільська цивілізація мала розгалужену систему міфологічних вірувань, уявлень, ритуалів та обрядів [2]. Якщо провести паралелі між періодами існування трипільської цивілізації та цивілізаціями Давнього світу, ми побачимо, що коли «історія починалася в Шумері», руїни їх поселень-гігантів, що налічували тисячі будівель і простягалися на сотні гектарів, вже давно лежали під землею [3, c. 44-45].

Серед трипільської кераміки трапляються особливі вироби - посудини без дна різних форм і розмірів. Вони дотепер не знайшли од-

(C) Олійник О., 2016 
нозначної інтерпретації. Відомі як спарені (що отримали назву «біноклі»), так і одинарні («моноклі») вироби (рис. 1). Існують різні версії їх функційного призначення. Найпоширенішою є думка, що вони використовувалися як підставки під посуд. Існували й інші версії їх застосування [6, с. 111-114]. Зрештою дослідники дійшли висновку, що ці вироби мали виключно культове призначення.
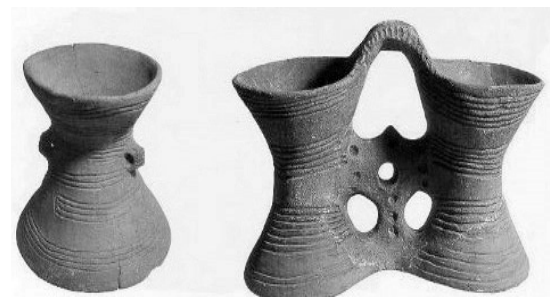

Рис. 1. Трипільські керамічні вироби без дна

Ще на початку XX ст. висловлювалось припущення, що біноклеподібні вироби були спареними барабанами. Пізніше це припущення a priori сприйняли й деякі інструментознавці [13, с. $21 ; 15$, с. 65]. Воно грунтувалося на факті існування у музичній практиці народів Азії та Кавказу спарених мембранофонів типу - литавр-нагора. Однак литаври-нагора, за міжнародною класифікацією музичних інструментів, належать до іншого типу мембранофонів - котло-барабанів (код 211.12) що, на відміну від барабанів, не мають отвору у нижній частині [10, с. 244]. Дотепер здійснюються спроби реконструкції цих виробів як барабанів. Я вважаю недопустимим видавати бажане за дійсне: до ідентифікації цих керамічних виробів як музичних інструментів треба ставитися вкрай обережно, оскільки доволі широкі верхні перемички більшості відомих екземплярів розташовані безпосередньо на краях вінець (рис. 2). Це заважає рівномірному натягу мембрани і позбавляє інструмент повноцінного звучання. Зважаючи на досконалість і витонченість трипільської кераміки та високий рівень цивілізації, навряд чи можливо, щоб трипільців міг задовольнити такий конструктивно недосконалий інструмент. Наприклад, автори реконструкції з Івано-Франківська для більш-менш рівномірного натягу мембрани змушені були максимально звузити ширину верхньої перемички, що, по-суті, робить ії історично недостовірною. Існує ще одна обставина, що залишилася поза увагою прибічників трактування посудин з широкою верхньою перемичкою як спарених барабанів. 
Зокрема, чим можна пояснити той факт, що у шістнадцяти житлових будинках, розкопаних поблизу с. Кліщів (Вінницька обл.), археологи знайшли одразу понад 250 «біноклів»? Відомо, що в кожному будинку одночасно могла проживати сім'я з 4-5 осіб [4, с.131]. Чи означає це, що всі без винятку мешканці осель (від старого до немовляти), мали по декілька барабанів? Більш логічним видається припущення, що ці спарені вироби могли бути символами або втіленнями певного божества чи комплексу міфологічних уявлень і використовуватися у щорічних обрядах та ритуалах.

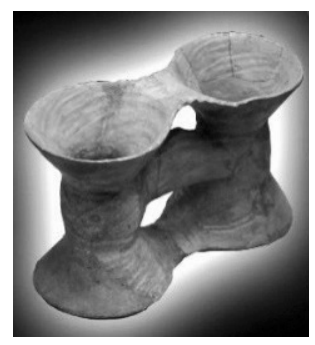

Рис. 2. Виріб з широкою перемичкою

Однак не варто остаточно відмовлятися від ідеї існування у трипільців спарених барабанів. І ось з яких причин. Серед локально-територіальних комплексів кераміки, поряд із значною кількістю «біноклеподібних» виробів з верхньою перемичкою, зрідка трапляються екземпляри без неї (рис. 3, б). На цей факт ніхто із дослідників чомусь не звернув уваги. Відсутність перемички дозволяє без жодних зусиль рівномірно натягнути мембрану. Подібні спарені керамічні барабани існували в інструментарії ацтеків Південної Америки (рис. 3, в). Ще раз зазначимо, що вироби без перемички трапляються вкрай рідко. Цей факт $є$ визначальним критерієм ідентифікації цих виробів як барабанів. Адже з історичних та етнографічних джерел відомо, що у різних народних традиціях, а також у давніх культурах кількість музичних інструментів, як і виконавців на них, складала незначний відсоток.

Більшість дослідників-археологів уважають, що біноклеподібні вироби мали виключно культове призначення і використовувалися в обрядах. Відомо, що в ритуалах та обрядах важливими є всі його складові: слово, музика, танець та атрибути, зокрема й музичні інструменти, що своєю формою та оздобленням утілювали їх зміст. К. Закс, до- 
слідник давніх музичних інструментів і один із засновників музичної археології, зазначав, що жоден з інструментів не мав такої кількості ритуальних функцій і не сприймався як найбільш священний, ніж барабан [14, с. 28]. Академік Б. Рибаков уважав, що біноклеподібні вироби використовували в аграрному обряді «напування землі», тобто в ці посудини без дна наливали воду, що проливалася через отвори на землю, зволожуючи їі [7, с. 16]. Якщо спарені вироби з верхньою перемичкою використовувалися в обряді і були його атрибутом, то звуковим супроводом цього дійства міг бути спарений барабан без перемички, який формою і декором відповідав змісту обряду.

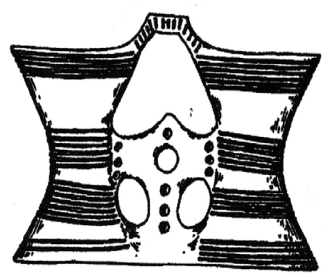

a

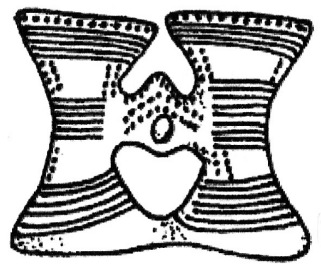

б

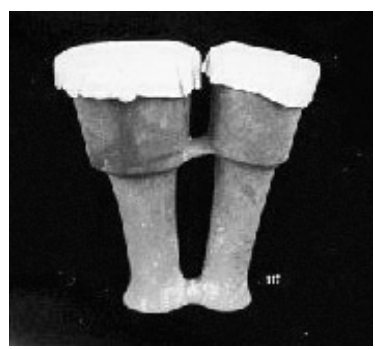

B

Рис. 3. а - біноклеподібний виріб з перемичкою; б - без перемички; в - спарений барабан ацтеків

На особливу увагу заслуговують так звані моноклі. Ці пустотілі вироби археологи інтерпретують як підставки під посудини. Однак на поверхні вінець жодного разу не було виявлено характерних потертостей та ушкоджень, що зазвичай залишаються від часто встановлюваних на них посудин. Натомість вони мають ряд характерних ознак, що дозволяють їх ідентифікувати як барабани. Зазначу, що серед загальної маси кераміки ці вироби трапляються вкрай рідко.

Оскільки барабани є одними з найдавніших музичних інструментів, що протягом тисячоліть у практично незмінному вигляді існують у традиційному інструментарії народів світу, для реконструкції окремих типів трипільських барабанів необхідно залучати аналоги як дотепер існуючих інструментів, так і археологічні артефакти, що однозначно ідентифікуються як барабани.

Окрема група «моноклів» має форму пісочного годинника (рис. 4 а). Керамічні барабани такої форми дотепер існують в Індії (рис. 4 б). За міжнародною класифікацією типів музичних інстру- 
ментів Е. Горнбостеля - К. Закса, інструмент з Індії належить до пісочно-годинникового типу барабанів (код 211.24) [10, с. 245]. Hе виключено, що трипільський барабан міг бути й двомембранним, тобто шкіри-мембрани могли натягатись на обидва отвори, як на індійському інструменті. Подібними до нього за формою та нанесеним орнаментом у вигляді заглиблених ліній є «біноклі» з верхньою перемичкою (рис. 2), а також спарені барабани (рис. 3 б), які за формою та оздобленням утворюють єдиний знаковий комплекс. Спарені барабани («біноклі» без перемички) у формі двох пісочних годинників та одинарний барабан (рис. 4 а) свідчать про те, що в межах одного типу могли існувати два варіанти інструмента.

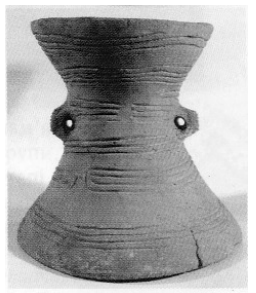

a

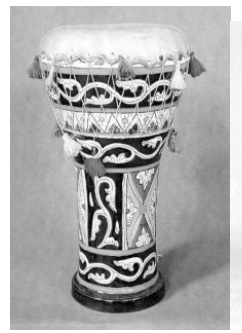

$\Gamma$

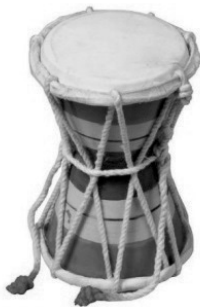

б

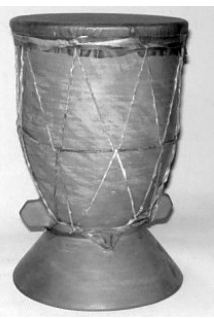

Д

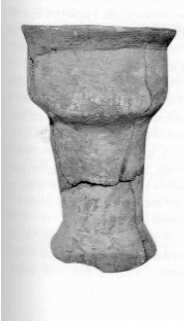

B

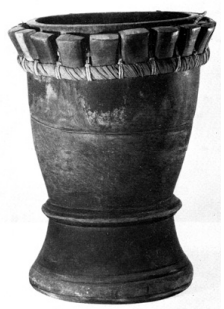

e

Рис. 4. Трипільські барабани та їх народні аналоги: a - у формі пісочного годинника; б - індійський барабан; в - келихоподібний; г - дарабука; д - конусний; е - барабан з Нової Гвінеї

Барабан, що належить до типу келихоподібних (код 211.26), виявлено автором серед керамічного матеріалу розкопок поблизу с. Ленківці (Чернівецька обл.). Він датується 4600 р. до н. е. (рис. 4, в). Автор розкопок Катерина Черниш інтерпретувала його як підставку під посудину [11, с. 68-70]. Керамічні барабани подібної форми дотепер 
існують в інструментальній практиці багатьох народів. Це турецький інструмент деблек, грецький тарабука, арабський дарабука або дарбок та ін. (рис. 4, г). Він також має аналогії серед археологічних знахідок у Німеччині, Польщі, Сгипті та Китаї.

Ще один різновид барабана, що належить до типу конусних (код 211.25), було знайдено поблизу с. Городниця на Західній Україні (Івано-Франківська обл.) (рис. 4, д). Він датується середнім етапом Трипілля (4500-4300 рр. до н. е.). У нижній, звуженій частині корпусу протилежно один до одного розташовано по два «вушка» та два невеликих виступи. Призначення цих деталей було незрозумілим і пояснювалося фахівцями як намагання надати виробу антропоморфних рис [1, с. 133]. На думку С. Бібікова, вушка зображають зігнуті у ліктях руки людини, яка тримає над головою чашу. Ця здогадка є слушною, однак це не є єдине їх призначення. На виготовленій точній копії барабана я провела експерименти з можливих способів натягу мембрани. Вони показали, що система іiі фіксації за допомогою ошнурування є максимально зручною та продуманою. Аналогічні за типом барабани виявлено також серед керамічного матеріалу в Кошилівцях (Тернопільська обл.), поблизу Березовської ГЕС на Південному Бузі, в Нових Русештах (Молдова). Корпуси цих інструментів прикрашені прокресленими орнаментами у вигляді змій. Археолог Наталія Бурдо, дослідниця духовної культури трипільської цивілізації, вважає, що подібні орнаментальні композиції на кераміці втілюють образ Місячної Богині-змії, що особливо вшановувалась трипільцями [2, с. 156]. 3 цього можна зробити висновок, що барабани з антропоморфними рисами могли використовуватися в обрядах, присвячених цій богині. Барабани аналогічної форми існують дотепер в традиційному інструментарії багатьох народів (рис. 4, е).

Досить цікаве відтворення обряду, що супроводжувався грою на барабанах, знайшли археологи поблизу с. Овчарово (Болгарія). У дуже зруйнованій моделі житла зберігалось 26 мініатюрних предметів, серед яких були статуетки людей, мініатюрні мисочки, посудини з покришками, столики, крісельця та три предмети циліндричної форми. На думку авторів знахідки, ці предмети циліндричної форми були барабанами типу там-тамів [9, с. 91-92]. Всі три циліндри мають різні розміри, що само собою є доволі показовим фактом. Зазвичай в інструментальній практиці, особливо при одночасному використанні декількох барабанів, їх настроювали так, щоб вони не звучали однаково, а мали відмінності у висоті звучання. Найпростіший спо- 
сіб їі досягнення - використання двох чи більше інструментів різних розмірів або різного діаметру отвору, на який натягається шкіра. Чим менша площа шкіри-мембрани, тим вищий звук, і навпаки. Різницю у звучанні можна також досягти за допомогою більшого чи меншого натягу шкіри. Не виключено, що на трипільських подвійних барабанах-«біноклях» для отримання різниці у висоті звучання могли застосовувати різну силу натягу однакових за розміром мембран.

У трипільців також існували й духові інструменти. Під час розкопок зрідка трапляються фаланги пальців бика з пробитими з одного боку отворами (рис. 5 а). Вони виявлені у трипільських поселеннях, зокрема в Луці-Врублівецькій [1, с. 60], Ленківцях [11, с. 86, табл. ХІІ] та ін. Інструментознавці добре знають цей кістяний музичний інструмент: це свисткова флейта. Найпростіші духові інструменти, виготовлені 3 фаланг тварин, знаходять під час археологічних розкопок на території всієї Європи (Франція, Данія, Чехія та ін.). В Україні вони відомі в археологічних культурах від доби палеоліту - до кінця доби бронзи [5, с. 179]. Прийнято вважати, що прості свисткові флейти були сигнальними інструментами або вабиками. Проте дослідження російських колег стосовно призначення деяких вабиків у неолітичних племен довели, що окремий тип вабиків використовувався виключно в обрядах, пов'язаних із культом птахів [8, с. 162]. Свисткові флейти трипільців також могли мати магічне значення. Як зазначала Н. Бурдо, за законами магії будь-які властивості речовини, з якої виготовлено предмети, могли перейти і на них. Бик у трипільців був пов'язаний з Великою Богинею, а річ, виготовлена з його кісток, набувала магічних властивостей [2, с. 44]. Це означає, що свисткова флейта з фаланги бика також могла належати до магічних інструментів.

У трипільців існували духові інструменти більш складної конструкції. Серед антропоморфної пластики трапляються зображення чоловіків, що тримають обома руками предмет, що має форму довгого валика з поперечними насічками (рис. 5, б). Існує думка, що це зображення жезла [3, с. 183]. Однак положення рук є типовим для тримання деяких духових інструментів (рис. 5, в). Цікавими також $€$ прокреслені поперечні насічки на інструменті. У народній практиці до нашого часу зберігся дуже давній спосіб виготовлення духових інструментів. Дерев'яну заготовку потрібної форми розколюють уздовж і вибирають серцевину, потім з'єднують дві половинки і скріплюють їх, обмотуючи навколо вивареною корою (рис. 5, г). Це робить інструмент схожим на стилізоване зображення змії. Подібно 
виготовлені інструменти дотепер існують в музичному інструментарії народів Європи, зокрема й українців. Це інструменти типу трембіти та дерев'яні труби менших розмірів.

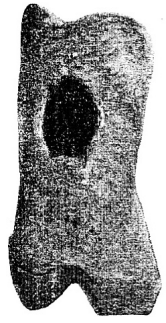

a

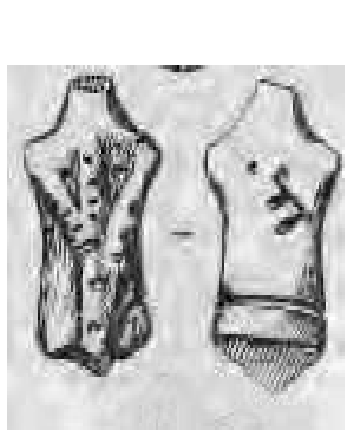

б

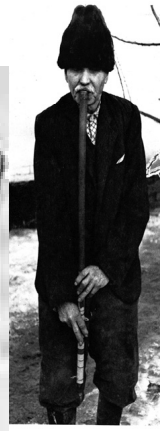

B

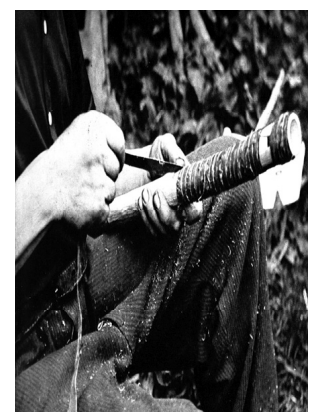

$\Gamma$

Рис. 5. Духові інструменти: а - трипільська свисткова флейта; б - трипільська труба; в - народний виконавець на духовому інструменті; г - спосіб обмотування корою корпусу духового інструмента

Слід зазначити, що труби, як і кістяні музичні роги, у багатьох народів світу з давніх часів асоціювались з чоловічою силою, ідеєю родючості. Їх надзвичайно потужні та різкі звуки ототожнювали з голосами зооморфних богів, зокрема й у подобі бика. Очевидно, труби, зображені на трипільських статуетках, якщо зважати на їх звучання, що нагадує ревіння бика, а також присутність у конструкції змієподібних рис (обмотаної навколо корпусу кори), могли бути пов'язаними з обрядами на честь Великої Богині трипільців і мати полісемантичне значення. Можливо, «жезли вождів» 3 поперечними насічками зображені у тій самій манері й на інших фігурках, втілювали ті самі ідеї.

Отже, на основі порівняльного інструментознавчого аналізу в сакральних комплексах трипільської кераміки виявлено три типи барабанів раннього й середнього етапів існування Трипільської цивілізації. Їх аналоги до нашого часу збереглися в традиційному інструментарії народів світу. Вони також відомі з археологічних розкопок пам'яток неоліту - доби бронзи на території Європи, Азії та Південної Америки.

У дослідженні музично-інструментальної культури трипільської цивілізації зроблено лише перші кроки. Представлені у статті ре- 
конструкції різних типів ударних і духових інструментів є лише незначною часткою зібраного автором величезного археологічного «музичного» матеріалу, який потребує поглибленого і всебічного інструментознавчого аналізу.

\section{СПИСОК ЛІТЕРАТУРИ}

1. Бибиков С. Н. Раннетрипольское поселение Лука-Врублевецкая на Днестре / С. Н. Бибиков // Материалы и исследования по археологии СССР. - М. ; Л. : Изд-во Академии наук СССР, 1953. - № 38. - 460 с.

2. Бурдо Н. Сакральний світ трипільської цивілізації / Наталія Бурдо. Київ : Наш час, 2008. - 296 с.

3. Відейко М. Ю. Шляхами трипільського світу / М. Ю. Відейко. - Київ : Наш час, 2007. - $296 \mathrm{c}$.

4. Заєць I. Трипільська культура на Поділлі / Іван Заєць. - Вінниця : Тезис, 2001. $-184 \mathrm{c}$.

5. Олейник О. Музыкальные инструменты палеолита - эпохи бронзы (по археологическим раскопкам на территории Украины) / Ольга Олейник // Инструментальная музыка в межкультурном пространстве: проблемы артикуляции: рефераты докладов и материалы Международной инструментоведческой конференции (Санкт-Петербург, 1-4 дек. 2008 г.). - СПб.: Астерион, 2008. - C. $178-181$.

6. Палагута И. «Биноклевидные» изделия в культуре Триполье-Кукутень: опыт исследования категории «культовых» предметов / Илья Палагута // Revista Arheologică. Serie nouă. - Chişinău, 2007. - Vol. III, Nr. 1-2. - P. 110137.

7. Рыбаков Б. А. Космогония и мифология земледельцев энеолита / Б. А. Рыбаков // Советская археология. - 1965. - № 2. - С. 13-33.

8. Сидоров В. Манок - музыкальный инструмент эпохи неолита / В. Сидоров //Народные музыкальные инструменты и инструментальная музыка : сборник статей и материалов : в двух частях. Часть первая. - Москва : Советский композитор, 1987. - С. 157-163.

9. Тодорова Х. Археологическо проучвание на праисторически обекти в района на с. Овчарово, Търговищко, през 1971-1974 // Овчарово. Розкопки и проучвания. IX. - София, 1983. - С. 7-105.

10. Хорнбостель Э. М. Систематика музыкальных инструментов (перевод И. 3. Алендера) / Эрих М. фон Хорнбостель, Курт Закс // Народные музыкальные инструменты и инструментальная музыка : сборник статей и материалов : в двух частях. Часть первая. - Москва : Советский композитор, 1987. - C. $229-261$.

11. Черниш К. К. Ранньотрипільське поселення Ленківці на середньому Дністрі / К. К. Черниш. - Київ : Вид-во АН УРСР, 1959. - 107 с.

12. Ancient Trypillia: Seven thousand years of spiritual art. - New York : FRAC, 2010. $-60 \mathrm{p}$. 
13. Buchner A. Encyklopedia instrumentów muzycznych (od czasów przedistorycznych do XX wieku /Alexander Buchner. - Racibórz: R. A. F. SCRiBA, 1995. $380 \mathrm{~s}$.

14. Sachs C. Historia instrumentów muzycznych / Curt Sachs ; tłum.S. Olędzki. - Warszawa, 1975. - $556 \mathrm{~s}$.

15. Seewald O. Beiträge zur Kenntnis der steinzeitlichen Musikinstrumente Europas / O. Seewald. - Wien : A. Schroll \& C $^{\circ}, 1934 .-156$ s.

Олейник О. Музыкально-инструментальная культура Трипольской цивилизации (к вопросу реконструкции). Статья посвящена вопросам реконструкции ударных и духовых инструментов раннего и среднего этапов существования Трипольской цивилизации (4600-3700 гг. до н. э.). На основе сравнительного инструментоведческого анализа в сакральных комплексах трипольской керамики обнаружены разные типы барабанов, имеющие аналоги среди однотипных керамических инструментов народов мира. Духовые инструменты трипольцев реконструированы на основе многочисленного однотипного инструментария различных археологических культур (палеолита - эпохи бронзы) и народных технологий их изготовления.

Ключевые слова: трипольские музыкальные инструменты, музыкальная археология, барабаны, духовые инструменты.

Oliinyk $O$. Musical and instrumental culture of Trypillian civilization (regarding reconstruction). Article is devoted to the reconstruction of percussions and wind instruments of the early and middle stages of Trypillian civilization (4600-3700 B. C. E.). Based on the comparative knowledge of instruments analysis for sacred complexes in Trypillian ceramics there were found different types of drums with analogues among similar ceramic instruments of nations. Wind instruments of Trypillians were reconstructed based on numerous similar instruments of various archaeological cultures (Paleolithic Age - Bronze Age) and popular technologies of their manufacture.

Keywords: Trypillian musical instruments, musical archaeology, drums, wind instruments.

Стаття надійшла до редакції 27.04.2016

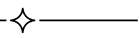

